\section{Rio Group}

The Group represents a regional forum for political consultation and policy co-ordination on major topics on the international agenda among 19 Latin American and Caribbean countries.

\section{Origin and development}

The Group was established at a meeting of eight Latin American Heads of State, held at Rio de Janeiro on 18 December 1986, as a Permanent Mechanism of Political Consultation and Co-ordination. Initially known as the 'Group of Eight', the Mechanism was the result of the fusion of the Contadora Group (Colombia, Mexico, Panama and Venezuela) and the Support Group (Argentina, Brazil, Peru and Uruguay), both concerned with political crises in Central America. Regional security arrangements and debt and development issues were the main focus of the Mechanism.

Panama was suspended from participation in October 1988, expelled in March 1990, and later readmitted after the return of a democratic government. The eight founder members have been progressively joined by other Central American and South American countries. The gradual enlargement of the Rio Group (as the Mechanism has become generally known since the early 1990s) has enhanced its importance as a framework for intraLatin American consultation and negotiation and joint political action vis-à-vis third countries and major multilateral institutions.

\section{Membership}

The Group consists of Argentina, Bolivia, Brazil, Chile, Colombia, Costa Rica, Dominican Republic, Ecuador, El Salvador, Guatemala, Honduras, Mexico, Nicaragua, Panama, Paraguay, Peru, Uruguay and Venezuela, plus Guyana that currently represents the countries of the Caribbean.

\section{Objectives}

The Group aims to expand political co-operation among member countries, to expedite the process of Latin American integration and promote co-ordination among Latin American organizations, to present appropriate solutions to the problems and conflicts affecting the region, to strengthen the initiatives and actions undertaken to improve interAmerican relations, and to explore new fields of co- operation in order to enhance economic, social, scientific and technological development. The liberalization of regional trade and the establishment of a free trade area are also among the objectives of the Group.

\section{Structure}

The Group has no legal status and no permanent headquarters. The annual summits of the Heads of State and regular meetings of the Foreign Ministers share the decision-making power. The Secretariat rotates between member countries according to the location of the summit meeting.

\section{Activities}

The Veracruz Act of March 1999 consolidated the objectives and principles that had materialized within the framework of the Group and stressed the importance of promoting democracy, protecting human rights and intensifying the fight against terrorism, corruption and drug trafficking. Over the past few years measures have been considered to reduce tariff and non-tariff barriers and to start a progressive co-ordination of macroeconomic policies.

\section{External relations}

The political and economic dialogue between the Group and the European Union (EU), institutionalized in December 1990 through regular meetings, is based on the tightening of political ties, the stepping-up of economic integration and free trade and the focusing of co-operation on priority areas. Cooperation is also being developed in the areas of social reform, consolidation of civil society, support for the private sector, and culture, education, science and technology. Increased investment and technology transfers and trade liberalization on the part of EU members have been repeatedly urged by the Group. The last Ministerial Conferences between the Group and the EU have dealt with several key issues including sustainable development; trade and investment; social cohesion and democratic governance; drug-trafficking; and the fight against transnational crime and terrorism.

The further development and effectiveness of the activities of the Group will depend also on closer coordination with other regional bodies such as the Latin American Economic System (SELA) and the Latin American Integration Association (LAIA). 